\title{
A review on one belt one road-China Pakistan economic corridor and its policy implications

\author{
Faiza Manzoor $^{a^{*}}$, Longbao Wei ${ }^{a}$, Abdul Latif ${ }^{b}$, Syed Irshad Ali Shah ${ }^{a}$ \\ ${ }^{a}$ Department of Agricultural Economics and Management, Zhejiang University, 310029 \\ Hangzhou, China \\ ${ }^{\mathrm{b}}$ Department of Management Sciences, Abbottabad University of Science and Technology, \\ Khyber Pakhtunkhwa, Pakistan \\ *Corresponding author: Faiza Manzoor, Agricultural Economics and Management, \\ faiza1885@yahoo.com
}

\begin{abstract}
The Belt and Road Initiative aims to promote the connectivity of Asian, European and African continents and the China-Pakistan Economic Corridor is one of its key ventures aiming for mutual cooperation and development of both the countries. Being termed as a "life-line" the project mainly focus on energy and infrastructure of Pakistan and the improvement of these sectors will serve as a driving source for Pakistan's economy. ChinaPakistan Economic Corridor with a proposed infrastructure from Gwadar to Kashghar and the other parallel projects would not only augment the Pakistan's industrial sector but also create a lot of employment opportunities. Similarly, China Pakistan Economic Corridor is equally important for China as it links China's western area and will serve as a shortest probable route to the markets Central Asia and other regions. China is giving its extra attention to improve the amenities at Gwadar port for increasing its existing capabilities thus enabling both the countries to equally reap its maximum benefits. The successful implementation of this plan would also encourage additional investment from other countries. Being an ongoing project, with its soft and smooth accomplishment the people from both the countries are expected to gain substantial benefits through China Pakistan Economic Corridor.
\end{abstract}

Keywords: One Belt One Road (OBOR), China Pakistan Economic Corridor (CPEC), Regional economies, Pak-China relations.

\section{Introduction}

Complex and profound changes are taking place in the world. The underlying impact of the international financial crisis keeps emerging; the world economy is recovering slowly, and countries still face big challenges to their development. The Belt and Road Initiative aims to promote the regional connectivity of Asian, European and African continents and their adjacent seas, establish and strengthen partnerships among the countries along the Belt and Road, set up all-dimensional, multi-tiered and composite connectivity networks, and realize diversified, independent, balanced and sustainable development in these countries. The connectivity projects of the initiative will help align and coordinate the development strategies of the countries along the Belt and Road, tap market potential in this region, promote investment and consumption, create demands and job opportunities and mutual 
learning among the peoples of the relevant countries, and enable them to understand, trust and respect each other and live in harmony, peace and prosperity (NDRC 2015 ${ }^{1}$ ).

As China's economy is closely connected with the world economy, so it is committed to the basic policy of opening-up, build a new pattern of all-round opening-up, and integrate itself deeper into the world economic system. The objective of the Silk Road projects should be China's economic upgrading, rebalancing, and further opening (J. Qingguo, 2015²). (W. Yanchun, $2015^{3}$ ) uses recent trade figures to explain the pressing need for China to "reconstruct its trade”. In addition to political objectives, One Belt One Road (OBOR) brings a strategic approach which encourages Chinese firms to go abroad in search of new markets or investment opportunities. The initiative is led from the Chinese government and the push for this initiative is backed by substantial financial investments by launching a $\$ 50$ billion Silk Road Fund that will directly support the project (EIU, 2015 ${ }^{4}$ ).

Under OBOR, China Pakistan Economic Corridor (CPEC) is part of the larger umbrella and aims to provide a new corridor of trade for China and Pakistan and is expected to benefit the whole of South Asian region. CPEC is designed to promote regional connectivity among Pakistan, China, and Eurasia (T. Shaohu, $2015^{5}$ ).The entire project is predicted to costUS\$57 billion, with much of this being financed by heavily-subsidised concessionary loans provided by the Exim Bank of China and China Development Bank (T. Mushtaq, 2017 $)$. The establishment of communication from Kashgar (China) to Gawadar - Baluchistan (Pakistan) has been agreed to be completed by 2030. For Pakistan, this corridor is viewed as a symbol of the indomitable relationship it shares with China. The bilateral relationship between both states is characterized by a high degree of mutual cooperation and convergence of strategic interests (Guardian, 2015 ${ }^{7}$ ). Hence, it could improve Pakistan's energy starved economy and the country's internal stability, if the projects materialize as envisioned. CPEC has a high value for both countries (China and Pakistan), due to CPEC the connectivity will open up west China to the south and contribute to "One Belt One Road” initiative policy.

\section{OBOR scenario}

The conceptual idea of OBOR is based on a historical narrative. A German traveller in the 1800s coined the phrase "Silk Road" to describe the route through which camels plied to bring goods from China to Europe through a series of intermediaries along the route (including the Persians, Arabs, Central Asians, etc.). Replacing the camels with high-speed rails (HSRs), the cotemporary Silk Route is modernized and brought up to date (L.T.Wei et al $2016^{8}$ ).In 2013, China's president, Xi Jinping, proposed establishing a modern equivalent, creating a network of railways, roads, pipelines, and utility grids that would link China and Central Asia, West Asia, and parts of South Asia (Figure 1).The OBOR initiative consists of the Silk Road Economic Belt and a New Maritime Silk Road. The Silk Road Economic Belt was unveiled by Xi Jinping at Nazarbayev University on September 7, 2013 as part of his state visit to Kazakhstan. The New Maritime Silk Road was announced before the Indonesian Parliament on October 3, 2013, as part of Xi Jinping's state visit to Indonesia (M. D. Swaine, $2015^{9}$ ). 


\section{CPEC and relationship of Pakistan and China}

Of the fourteen countries bordering China, relations with Pakistan are the friendliest (W.Shen, $2012^{10}$ ). The two countries established relations in 1951, when Pakistan was the first Islamic country to recognize the PRC (People's Republic of China). Since then, the closeness of the two countries has manifested in the form of bilateral interactions ( $R$. Lee, $2016^{11}$ ).In the relationship's relatively short history, the two countries have supported each other in areas ranging from nuclear weaponry to diplomatic assistance (M. Malik, 2003 ${ }^{12}$ ). As is the case with most bilateral agreements in today's world, there is more to CPEC than the stated goal of improving socioeconomic conditions in Pakistan. If implemented correctly, CPEC would deliver a much-needed kick to the Pakistani economy. CPEC aims to link the deep-water port of Gwadar, on the southwest coast of Pakistan, to China's Xinjiang region in the West of the country, through a series of transport routes, energy infrastructure, and communication networks (M.Farid, $2017^{13}$ ).

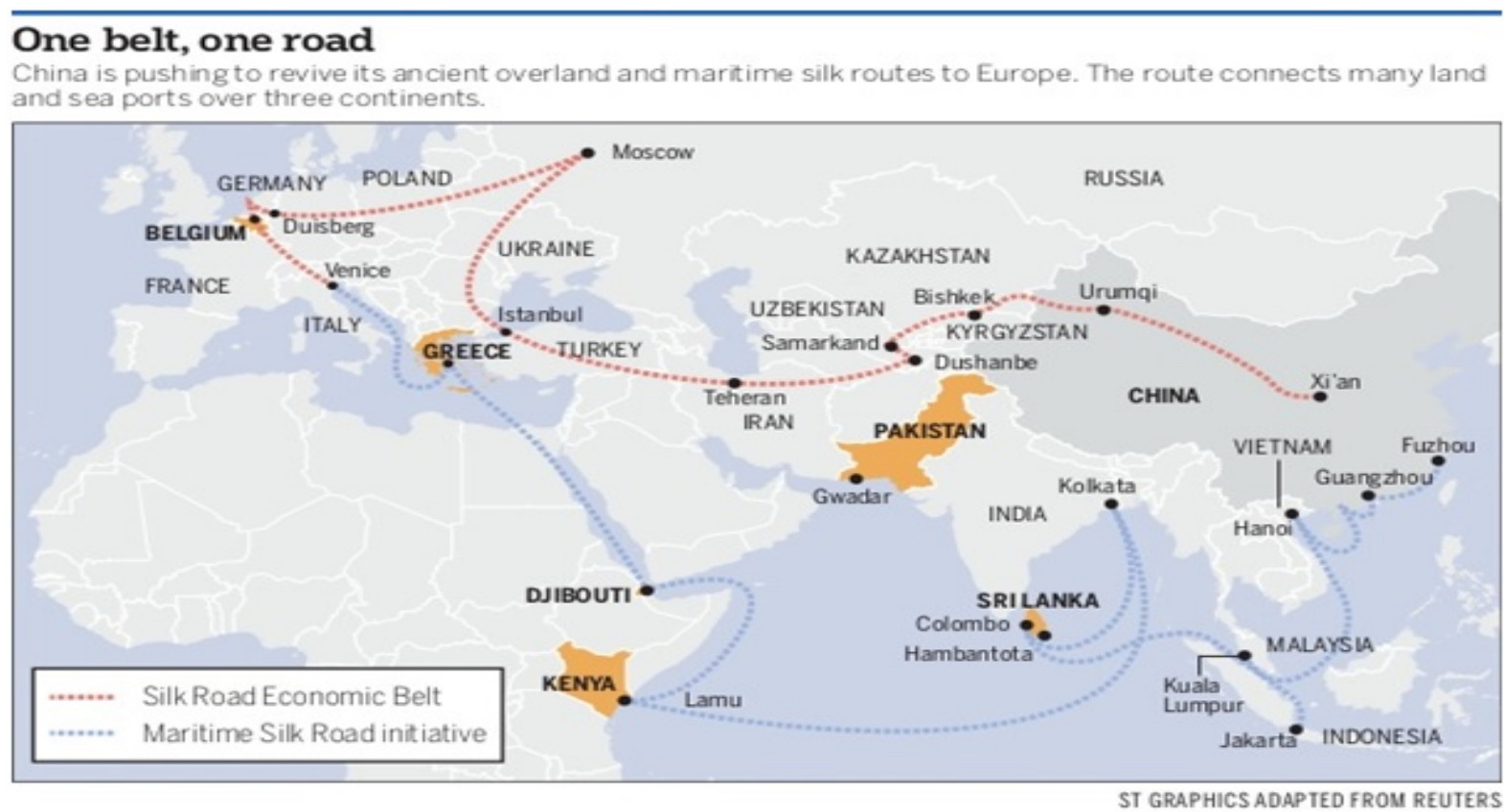

Fig1: https://cn.bing.com/images/search?view=detailV2\&ccid=LHIKaZPs\&id=816A9CC2F79E0AE7C310FA24A2384CBA 51501F66\&thid=OIP.LHIKaZPsHht018XqbuDowQEsDU\&q

The project would create new transport infrastructure which would improve the country's links with Asia, Europe and Africa, reduce investment and trade barriers, create a sound business environment that would attract foreign businesses, and lift millions of Pakistanis out of poverty (U.Javaid, 2016 ${ }^{14}$ ). South Asian geopolitics is often in a state of flux, with Pakistan having to adapt their domestic and foreign policy accordingly. The country has identified increased India-US cooperation as an attempt to counter the China-Pakistan relationship (T. Hussain, $2017^{15}$ ). For many years now, Pakistan has viewed the US as an unreliable ally and has attempted to decrease their dependence on US defence and economic support by aligning with China. China’s investment of US\$57 billion in CPEC has already eclipsed US investment in Pakistan during the period of 2009-2015, which amounted to a relatively small sum of US\$5 billion (S.A. Zaidi, 2016 ${ }^{16}$ ). The announcement of CPEC is also timely, with the new US president, Donald Trump, stating he wants to foster better relations 
with India while criticising Pakistan's lack of support of the US in the "War on Terror" (S. Shams, $2016^{17}$ ).

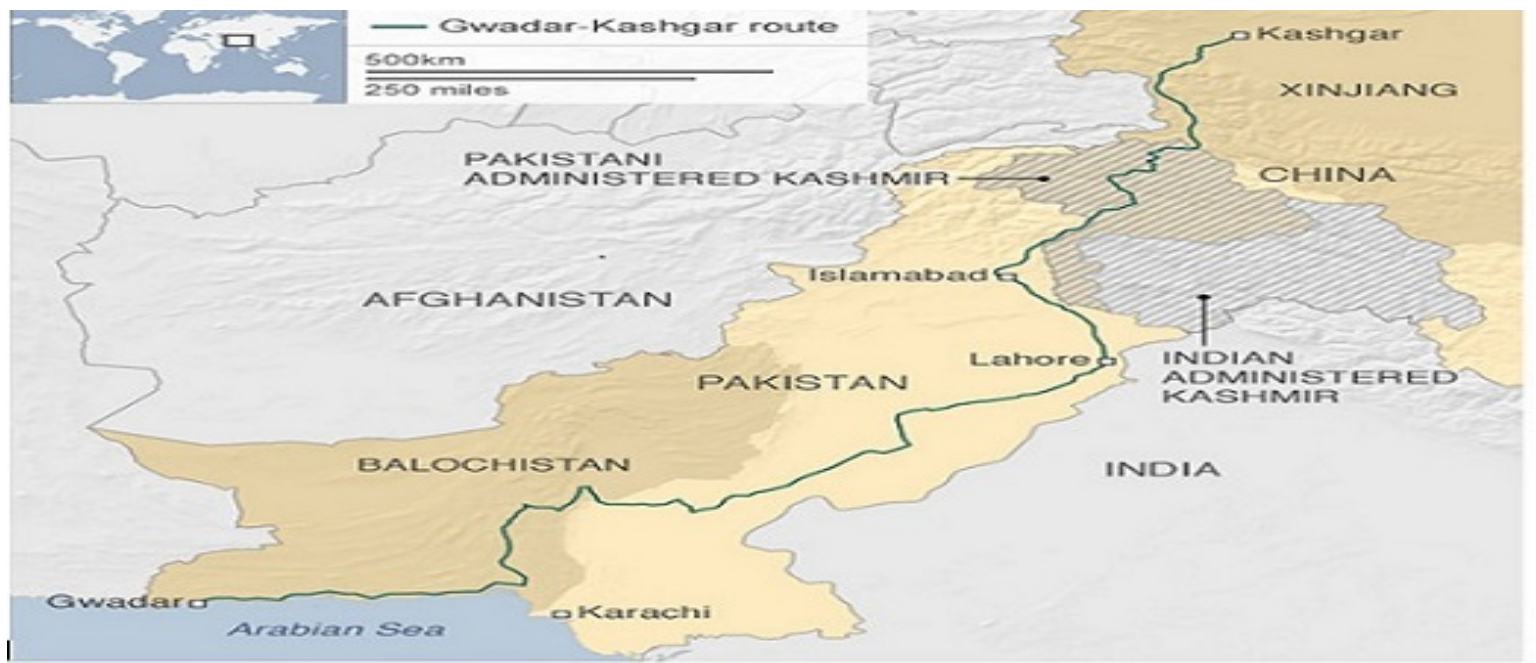

Figure2:The Proposed China-Pakistan Economic Corridor. (H.Zargar, 2017 $7^{18}$ )

source:http://mvkashmir.com/2017/03/21/china-pakistan-economic-corridor-re-aligning-realities/

It is hoped that CPEC would boost the connectivity of provinces such as Xinjiang, attracting both domestic and foreign companies to set up new operations in the region. Pakistan could act as a "transit facility", providing western Chinese provinces with access to Central Asian markets and the Indian Ocean (M. Khan, 2006 ${ }^{19}$ ). Furthermore, CPEC has the potential to make a country that has become the world's second largest importer of oil, energy secure (U.EIA, $2013^{20}$ ). With imported oil accounting for 54.8\% of the country's supply, CPEC could reduce the distance travelled by oil being imported from the Persian Gulf and East Africa significantly while also reducing the time taken by approximately 20 days (Z. Zhang, $2011^{21}$ ).

As is the case with Pakistan, China is looking to develop and consolidate its military and economic influence in Asia, the Indian Ocean, and East Africa. China is not only building economic agreements, but creating institutions through which countries participating in the OBOR project can further align themselves with Chinese ideology. For example, in 2015, China finalised plans for the Asian Infrastructure Investment Bank (AIIB) and finally the AIIB was created with the support of fifty-seven countries, including US allies Germany and the United Kingdom ( $\mathrm{J}$. McBride, $2015^{22}$ ). Many see this as an attempt by China to undercut the influence of Western institutions, such as the World Bank.

\section{CPEC Opportunities for China and Pakistan}

There is a fair division of projects between the four provinces of Pakistan: 16 in Baluchistan, 8 in KPK, 13 in Sindh and 12 in Punjab. Out of the total projects, 16 are currently in process of incipient development, all part of the early harvest plan which are projects stipulated to be completed by 2016-2020 (Chinese Embassy, 2016 ${ }^{23}$ ).Three routes have been earmarked for CPEC; the western, central and eastern routes (Figure 2). The distribution of the corridor along three routes allows for access through all the four provinces and creating direct and indirect job possibilities (Staff Reporter, 2015 ${ }^{24}$ ). 
Pakistan's economy has tremendous strategic development potential, as it is located at the crossroads of South Asia, Central Asia, China and the Middle East. The major obstacles faced by Pakistan's economy include persistent industrial losses due to energy crisis, low foreign direct investment (FDI), lack of infrastructure development, losses due to war on terror and low exports and high imports(Dawn, 2016 ${ }^{25}$ ). Under CPEC, a grand total of 21 energy projects have been planned. Altogether, these projects would eventually produce 16,400 megawatts of power, roughly the same as Pakistan's current capacity. Also, 14 Chinese constructed energy projects in Pakistan tied to the CPEC are expected to provide an additional 10,400 megawatts of electricity by March 2018 more than sufficient to make up for Pakistan's 2015 energy shortfall of 4,500 megawatts (S.Tiezzi, 2016 ${ }^{26}$ ).CPEC will build a road from Gwadar to Kashghar and other road projects, which would enhance the capacity of Pakistan's industrial sector and strong industry would ensure a lot of job opportunities available to the talented youth (A. Hussain, 2017 ${ }^{27}$ ).

One of CPEC's primary objectives is to look to address pressing infrastructural requirements of Pakistan. With nearly \$11 billion earmarked for infrastructure development the road and railway network will greatly benefit Pakistan's economy. The road infrastructure will see development along Khuzdar-Basima Highway, Karakoram Highway II, Karachi Lahore Motorway and other projects. These development projects will enhance the connectivity between all four provinces and allow for ease of access of goods. Pakistan Railways is set to attract up to \$5 billion investment for the purpose of upgrading and deployment of new railways infrastructure across Pakistan. To enhance connectivity and improve transportation facilities up gradation of 1,872 kilometres track from Karachi to Peshawar will be carried out. Other projects for the railway infrastructure include $1,254 \mathrm{~km}$ of railway track from Kotri to Attock city that will be upgraded (Pakistan observer, $2017^{28}$ ).

Residents of Pakistan's south-western port city of Gwadar will enjoy better emergency medical treatment, the hospital was donated by the Red-Cross Society of China and is the first of its kind along the CPEC, and adjacent to the newly built hospital is school, opened in September 2016, the school was the first China-donated project aimed at improving the livelihood of people along the CPEC. Another training school will also be built within the next couple of years in Gwadar to help young people master a skill so that they have a means to earn a life in the future. Meanwhile, China State Construction Engineering Corporation (CSCEC), which has a branch in central Pakistan's historical city of Multan, is also engaged in projects that direct have an impact on the lives of the locals (Xinhua, 2017 ${ }^{29}$ ).

Centre for Global \& Strategic Studies (CGSS) held a seminar in April 2017 "On the Belt and Road initiative” in Islamabad and during the seminar Mr. Zhao Lijian said that CPEC was a promising venture which had not only given a boost in the economic performance of Pakistan but also further strengthened bilateral diplomatic and strategic relations between Pakistan and China. Various aspects of the CPEC are being continuously analysed which is a sign of individuals and institution's growing interest in it, he said (Z.Qureshi, 2017 ${ }^{30}$ ).

Almost $80 \%$ of the China's oil is currently transported from Strait of Malacca to Shanghai, (distance is almost 16,000 km and takes 2-3 months), with Gwadar becoming operational, the distance would reduce to less than 5,000 km(F.U.Zaman, 2016 ${ }^{31}$ ). As part of infrastructure projects worth approximately $\$ 11$ billion, and 1,100 kilometre long motorway will be constructed between the cities of Karachi and Lahore (Staff Reporter, 2014 ${ }^{32}$ ).The Karachi- 
Peshawar main railway line will also be upgraded to allow for train travel at up to 160 kilometres per hour by December 2019. Pakistan's railway network will also be extended to eventually connect to China's Southern Xinjiang Railway in Kashgar (S. Zhen, 2015 ${ }^{33}$ ).

\section{Conclusions and Recommendation}

OBOR is a regional connectivity strategy that comprises 65 countries and six economic corridors and caters to two-thirds of the world's population. CPEC is one of the six economic corridors proposed under the OBOR initiative. CPEC is a multibillion dollar initiative which aims to facilitate trade along an overland route that connects Kashgar and Gwadar, through construction of a network of highways, railways and pipelines and is considered an extension of China's ambitious OBOR initiative. Also, CPEC will be helpful in economic opportunities not only to Pakistan but will physically connect China to its markets in Asia, Europe and beyond. Investments in infrastructure and energy sector have given confidence to local businessmen that frequent power outages which had become a norm since the past decade would be addressed. As the CPEC investment is seen integral to Pakistan's growth. Furthermore, for countries along the CPEC, the corridor is not only about economic gains, but also about cross-cultural and people-to-people contact, which could involve the likes of Iran, Afghanistan and other Central Asian countries. It is not only an economic issue. It is also cultural because cultural means people to people.

These types of projects and activities should continue time to time between Pakistan and China for the more development of both countries. These types of activities will be helpful in reducing the poverty and will create more chances of employment; furthermore, these kinds of projects would be very supportive in the country's economy and development. Focusing on the successive implementation of projects and development of an effective corridor will lead to cross cultural and people-to-people contact. There is a need of an active involvement of the other economies in the region specially Iran, Afghanistan and other Central Asian countries. By taking into consideration the development of agriculture sector of Pakistan and provision of China's expertise in the agriculture sector, the true benefit of this initiative can be tickled down to a common man.

\section{References}

1. NDRC, (National Development and Reform Commission). Vision and Actions on Jointly Building Silk Road Economic Belt and 21st-Century Maritime Silk Road. People's Republic of China, Available at URL: http://en.ndrc.gov.cn/newsrelease/201503/t20150330_669367.html(28.3.2015).

2. J. Qingguo, “A number of issues that the OBOR urgently needs to clarify and prove”, Aisixiang, 24 March 2015.

3. W. Yanchun, "Reconstructing China’s trade”, Caijing, 2 February (2015).

4. EIU (The Economist Intelligence Unit Limited), Prospects and challenges on China's 'one belt, one road': a risk assessment report, Available at URL: https://www.eiu.com/public/topical_report.aspx?campaignid=OneBeltOneRoad(201 5). 
5. T. Shaohu., Vision and actions on jointly building Belt and Road. English News Available at URL: http://news.xinhuanet.com/english/china/201503/28/C_134105858.htm(28.03.2015).

6. T. Mushtaq.,China-Pakistan Economic Corridor :Available at URL: http://dailytimes.com.pk/features/16-Feb-17/china-pakistan-economic-corridoraninsight(2017).

7. Guardian, China to unveil $\$ 46 \mathrm{bn}$ investment in Pakistan during visit by $\mathrm{Xi}$ Jingping.Available at URL: https://www.theguardian.com/world/2015/apr/20/china-tounveil-46bn-investment-in-pakistan-during-visit-by-xi-jingping (20.4.2015)

8. L. T. Wei., H. H. L. Chan, K. H. Y. Tseng, \& W. X. Lim., China's one belt one road initiative. World Scientific. (2016).

9. M. D. Swaine, Chinese views and commentary on the 'One Belt, One Road'initiative. China Leadership Monitor, (2015) 47(2), 3.

10. W. Shen, China and its Neighbours: troubled relations. Available at URL: http://www.euasiacentre.eu/pub_details.php?pub_id=46 (1.03.2012).

11. R. Lee,The Strategic Importance of Chinese-Pakistani Relations. Al Jazeera Centre for Studies (2016).

12. M. Malik, The China factor in the India-Pakistan conflict. Parameters, (2003) 33(1), 35.

13. M. Farid, CPEC: The light at the end of the tunnel? Available at URL: https://global.factiva.com/redir/default.aspx?P=sa\&NS=16\&AID=9KIN002300\&an=ASE NER0020170307ed3v00002\&cat=a\&ep=ASI(2017)

14. U. Javaid, Assessing CPEC: Potential Threats and Prospects. Journal of the Research Society of Pakistan, (2016) 53(2).

15. T. Hussain, How India-Pakistan Tensions (and US-Chiina Rivalry) Are Raising Nuclear Stakes.South China Morning Post. Available at URL: http://www.scmp.com/weekasia/geopolitics/article/2026150/how-india-pakistan-tensions-and-us-china-rivalry-areraising. (8.10.2016)

16. S. A. Zaidi, The new game changer in Pakistan. Available at URL:http://www.thehindu.com/opinion/lead/The-new-game-changer-inPakistan/article14342869.ece(28.05.2016).

17. S. Shams,Economic corridor - CPEC could turn Pakistan into China's 'client state'. Available at URL: http://www.dw.com/en/economic-corridor-cpec-could-turn-pakistaninto-chinasclient- state/a-36384662 (14.11.2016).

18. H. Zargar, China Pakistan Economic Corridor: Re-Aligning Realities. Available at URL: http://mvkashmir.com/2017/03/21/china-pakistan-economic-corridorre-aligning-realities/(21.03.2017).

19. $M$. Khan,New Heights of Pak-China Ties. Available at URL: http://usa.mediamonitors.net/content/view/full/27754 (3.01.2006).

20. U. EIA, Annual energy outlook 2010. US Energy Information Administration, Washington, DC, (2013) 60-62.

21. Z. Zhang, China's energy security, the Malacca dilemma and responses. Energy policy, 39(12), (2011) 7612-7615.

22. J. McBride,Building the New Silk Road. Available at URL: http://www.cfr.org/asia-andpacific/building-new-silk-road/p36573 (22.05.2015). 
23. Chinese Embassy, Associated press of Pakistan. Available at URL:http://www.app.com.pk/16-cpec-projects-in-balochistan-8-in-kpk-chinese-embassy/ (5.10.2016).

24. Staff Reporter, Ahsan reveals three routes of corridor. Available at URL: $\quad$ https://www.dawn.com/news/1182074/ahsan-reveals-three-routes-ofcorridor(15.5.2015)

25. Dawn,7 facts about Pakistan's energy crises and how you can help end it. Available at URL: http://www.dawn.com/news/1275116. (5.8.2016.)

26. S. Tiezzi, China Powers up Pakistan: The Energy Component of the CPEC. Available at URL: http://hediplomat.com/2016/01/china-powers-up-pakistan-the-energy-componentof-the-cpec/(13.01.2016).

27. A. Hussain,CPEC Benefits and Challenges. Pakistan observer. Available at URL: http://pakobserver.net/cpec-benefits-challenges/ (2017).

28. Pakistan observer, CPEC: A Corridor of Opportunities. Available at URL: http://pakobserver.net/cpec-corridor-opportunities/ (2017).

29. Xinhua,China-Pakistan Economic Corridor benefits Pakistani people. ShanghaiDaily.com. Available at URL: http://www.shanghaidaily.com/nation/ChinaPakistan-EconomicCorridor-benefits-Pakistani-people/shdaily.shtml(11.05.2017).

30. Z. Qureshi,CPEC to boost trade, industrial growth in Pakistan. Pak Observer. Available at URL: http://pakobserver.net/cpec-boost-trade-industrial-growth-pakistan/(2017).

31. F.U. Zaman,Foolproof CPEC plan set in motion. The Nation. Available at URL: http://nation.com.pk/national/31-Dec-2016/foolproof-cpec-plan-set-in-motion (31.12.2016).

32. Staff Reporter, Karachi to Lahore Motorway Project Approved. Dawn. Available at URL: https://www.dawn.com/news/1116948(4.07.2014).

33. S. Zhen, "Chinese firm takes control of Gwadar Port free-trade zone inPakistan" South China Morning Post. Available at URL: $\quad$ http://www.scmp.com/business/companies/article/1877882/chinese-firm-takescontrol-gwadar-port-free-trade-zone-pakistan(11.11.2015). 